\title{
Meningkatkan Hasil Belajar Siswa Pada Konsep Perubahan dan Pelestarian Lingkungan Hidup dengan Model Discovery Learning di SMAS Katolik ST Gabriel Maumere
}

\section{Improving Student Learning Outcomes on the Concept of Change and Environmental Conservation with the Discovery Learning Model in ST Gabriel Maumere Catholic High School}

\author{
Mansur $\mathbf{S}^{1 *}$, Yohanes Bare ${ }^{1}$ \\ ${ }^{1}$ Universitas Nusa Nipa, Jln. Kesehatan No. 03, Maumere, Indonesia 86111 \\ *1 Email Korespondensi: mansursaputra00@gmail.com \\ doi: http://dx.doi.org/10.29405/ j.bes/ 3284-893298
}

Received:06 Maret 2019 | Accepted: 30 Agustus 2019 | Published: 31 Desember 2019

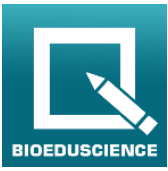

\begin{abstract}
Abstrak
Background: Hasil belajar merupakan kemampuan tertentu baik secara kognitif, afektif maupun psikomotorik yang dicapai oleh siswa setelah mengikuti pembelajaran. Penelitian tindakan kelas (PTK) yang digunakan dalam penelitian ini, dengan tujuan untuk meningkatkan hasil belajar siswa SMAS Katolik St Gabriel Maumere pada konsep perubahan dan pelestarian lingkungan hidup, melalui penerapan model Discovery Learning. Metode: Penelitian Tindakan Kelas ini dilaksanakan pada siklus I dan siklus II dengan setiap siklus terdiri dari dari dua kali pertemuan. Presentase ketuntasan dari siklus I adalah $55 \%$ yang selanjutnya dilakukan siklus II dengan hasil presentase ketuntasan 90\%. Hasil: penelitian yang dilakukan menunjukan adanya peningkatan hasil belajar siswa yang dilihat dari siklus II. Kesimpulan: Dengan demikian model Discovery Learning terbukti dapat meningkatkan hasil belajar siswa pada konsep perubahan dan pelestarian lingkungan hidup.
\end{abstract}

Kata kunci: Discovery Learning; Hasil Belajar; Lingkungan Hidup.

\begin{abstract}
Background: Learning outcomes are certain abilities that are cognitive, affective and psychomotor achieved by students after participating in learning. Classroom Action Research (CAR) used in this study, with the aim of improving the learning outcomes of St. Gabriel Maumere Catholic High School students on the concept of change and environmental preservation, through the application of the Discovery Learning model. Method: This Classroom Action Research was conducted in cycle I and cycle II with each cycle consisting of two meetings. The percentage of completeness of the first cycle is 55\%, then the second cycle is done with a percentage of completeness of 90\%. Results: research conducted showed an increase in student learning outcomes seen from the second cycle. Conclusion: Thus the Discovery Learning model is proven to improve student learning outcomes on the concept of change and environmental preservation.
\end{abstract}

Keywords: Discovery Learning; Outcomes; Concept of change and environmental conservation.

Cara citasi: S, Mansur \& Bare, Y. (2019). Meningkatkan Hasil Belajar Siswa Pada Konsep Perubahan dan Pelestarian Lingkungan Hidup dengan Model Discovery Learning di SMAS Katolik ST Gabriel Maumere. BIOEDUSCIENCE: Jurnal Pendidikan Biologi dan Sains, 03(02): 84-89. Doi: http://dx.doi.org/10.29405/ j.bes/ 3284-893298

(C) 2019 Oleh authors. Lisensi Bioeduscience, Uhamka, Jakarta. Artikel ini bersifat open access yang didistribusikan di bawah syarat dan ketentuan Creative Commons Attribution (CC-BY) license. (http://creativecommons.org/licenses/by/4.0/). 


\section{PENDAHULUAN}

Pendidikan merupakan proses yang dilakukan secara sengaja guna menambah pengetahuan, wawasan, dan pengalaman. Pendidikan berfungsi untuk menciptakan generasi yang berkualitas. Pendidikan dilakukan melalui proses pembelajaran dengan tujuan untuk mengembangkan seluruh proses pembelajaran dalam komponen pendidikan yang melibatkan siswa dan guru. Guru dalam proses pembelajaran dituntut mampu memotivasi siswa, menggunakan beragam model dan media pembelajaran untuk membantu siswa mengkonstruksi materi pelajaran. Pendidikan idealnya diarahkan pada proses menemukan konsep dan memberdayakan kemampuan berpikir siswa dengan lebih optimal (Febriana, Sajidan., \& Prayitno, 2015).

Pendidikan diartikan sebagai usaha sadar dan terencana untuk mewujudkan suasana belajar dan proses pembelajaran. Suasana belajar diciptakan agar dapat meningkatkan semangat belajar siswa. Pendidik harus mampu menciptakan suasana belajar yang menarik sehingga siswa aktif dalam pembelajaran. Siswa secara aktif mengembangkan potensi dirinya untuk memiliki kekuatan spiritual keagamaan, pengendalian diri, kepribadian, kecerdasan, akhlak mulia, serta keterampilan yang diperlukan dirinya, masyarakat, bangsa dan Negara (Sugiyono, 2017).

Pendidikan merupakan kebutuhan manusia yang selalu mengalami perubahan karena adanya perkembangan disegala bidang kehidupan. Pendidikan pada dasarnya merupakan interaksi pendidik (guru) dengan peserta didik (siswa). Interaksi yang dimaksud yaitu saling mempengaruhi antara pendidik dengan siswa. Pendidikan berfungsi mengembangkan apa yang secara potensi dan aktual telah dimiliki siswa. Peran guru dalam hal ini adalah mengembangkan lebih lanjut pengetahuan yang dimiliki siswa semaksimal mungkin serta mendorong siswa atau memotivasi siswa pada saat pembelajaran.

Mata pelajaran biologi merupakan pembelajaran yang menekankan pada pemberian pengalaman secara langsung karena itu siswa dibantu untuk mengembangkan keterampilan sehingga menjadi pengalaman belajar bagi siswa (Febriana et al., 2015). Keterampilan disini meliputi keterampilan mengamati, menunjukan hipotesis, mengajukan pertanyaan dan mampu memberikan jawaban yang logis. Proses pembelajaran dikembangkan melalui tiga ranah yaitu kognitif, afektif dan psikomotorik (Sukardi, Wigati, \& Masripah, 2015).

Djamarah \& Zain (2010) menyatakan bahwa kegiatan belajar mengajar adalah suatu kondisi yang dengan sengaja diciptakan. Guru menciptakan kegiatan belajar guna membelajarkan peserta didik. Perpaduan dari kedua unsur manusiawi ini lahirlah interaksi edukatif dengan memanfaatkan bahan sebagai mediumnya. Semua komponen pengajaran diperankan secara optimal guna mencapai tujuan pengajaran yang telah ditetapkan sebelum pengajaran dilaksanakan (Hamalik, 2015).

Tujuan dari kegiatan belajar mengajar tidak akan pernah tercapai selama komponenkomponen lainnya tidak diperhatikan, salah satunya metode pembelajaran. Metode adalah salah satu alat untuk mencapai tujuan, dengan memanfaatkan metode secara akurat, guru akan mampu mencapai tujuan pengajaran (Hamdani, 2011). Keterampilan yang dimiliki anak didik dapat diwujudkan, apabila metode yang digunakan sesuai dengan tujuan yang dirumuskan. Antara metode dan tujuan seharusnya tidak bertolak belakang. Metode harus menunjang pencapaian tujuan pengajaran. Apabila metode yang digunakan tidak sesuai dengan tujuan yang telah dirumuskan maka keterampilan anak didik tidak dapat terwujud dengan baik (Djamarah \& Zain, 2010).

Keberhasilan seorang guru dipengaruhi oleh model pembelajaran yang diterapkan pada saat proses pembelajaran. Guru diharapkan dapat maksimal dalam menerapkan model pembelajaran yang kreatif agar siswa menyenangi pembelajaran. Guru harus mempunyai kemampuan memilih dan menentukan model pembelajaran untuk meningkatkan hasil belajar. Proses pembelajaran 
dengan model konvensional pada umumnya kurang menarik perhatian siswa dan dapat membuat siswa cepat bosan. Model pembelajaran tersebut juga dapat membuat siswa kurang berpartisipasi aktif dalam proses pembelajaran, dengan kata lain siswa bersifat pasif, tidak terlibat, atau hanya mendengar, menonton dan mencatat.

Hasil belajar siswa merupakan indikator atau gambaran keberhasilan guru dalam melaksanakan proses belajar mengajar. Masalah hasil belajar siswa tidak akan selesai dibicarakan dalam dunia pendidikan. Banyak faktor yang mempengaruhi hasil belajar siswa, antara lain model pembelajaran yang diterapkan oleh guru di dalam kelas, lingkungan belajar siswa dan media pembelajaran guru yang berakibat pada rendahnya hasil belajar. Kualitas proses pembelajaran dapat ditingkatkan, apabila guru memahami hal-hal yang mempengaruhi proses belajar siswa. Guru juga harus memahami dan dapat mengaplikasikan model pembelajaran yang efektif agar membantu siswa untuk belajar secara optimal sehingga dapat meningkatkan hasil belajar siswa.

Hasil observasi dan wawancara dengan guru mata pelajaran biologi di SMAS Katolik St Gabriel Maumere (pada tanggal 29 januari 2018), permasalahan yang dialami saat pembelajaran adalah siswa kurang antusias dan aktif ketika proses pembelajaran berlangsung, pembelajaran masih cenderung berpusat pada guru (teacher centered). Dalam pembelajaran, siswa tidak terpacu untuk menemukan atau mencari informasi-informasi mengenai materi pembelajaran yang sedang dipelajari. Hal ini menyebabkan tidak semua hasil belajar pada mata pelajaran biologi mencapai kriteria ketuntasan minimal (KKM) yang telah ditetapkan yaitu 76 .

Upaya mengatasi masalah tersebut di atas, diperlukan suatu model pembelajaran yang dapat digunakan untuk membuat pembelajaran lebih aktif. Discovery learning merupakan salah satu model pembelajaran yang mampu mengaktifkan siswa. Model discovery learning adalah model mengajar yang mengatur pembelajaran sedemikian rupa, sehingga anak memperoleh pengetahuan yang sebelumnya belum diketahuinya. Pengetahuan yang diperoleh anak tidak sepenuhnya melalui pemberitahuan, tetapi sebagian atau seluruhnya ditemukan sendiri. Discovery learning merupakan suatu kegiatan pembelajaran yang dirancang sedemikian rupa sehingga siswa dapat menemukan konsep konsep dan prinsip-prinsip melalui proses mentalnya sendiri.

Penelitian yang dilakukan oleh Istiana, Catur. A. N. \& J. (2015) menyatakan penerapan model discovery learning dapat meningkatkan aktivitas belajar (37.00\% pada siklus I meningkat menjadi $77,78 \%$ pada siklus II). Sedangkan penelitian yang dilakukan oleh Wahjudi (2015), menyimpulkan bahwa pembelajaran discovery learning dapat meningkatkan aktifitas dan hasil belajar siswa. Penelitian serupa dilakukan oleh Fitriyah Murtadlon\& Warti (2017), menyatakan bahwa hasil belajar matematika siswa yang menggunakan model discovery learning lebih baik dari hasil belajar matematika siswa yang tidak menggunakan model discovery learning (model konvensional).

Dalam penelitian ini peneliti memilih menggunakan model Discovery learning dengan melihat hasil belajar siswa seperti yang telah diteliti oleh peneliti-peneliti terdahulu. Penelitian ini sangat penting dan perlu dilakukan karena sebagian besar hasil belajar biologi siswa masih rendah dan belum mencapai kriteria yang ditentukan.

\section{MATERI DAN METODE}

Penelitian ini merupakan penelitian tindakan (action research) yang dilakukan di dalam kelas, atau penelitian tindakan kelas (Classroom Action Research). Penelitian tindakan kelas adalah penelitian yang dilakukan oleh guru dikelas dengan cara (1) merencanakan, (2) melaksanakan (3) mengamati dan (4) merefleksikan tindakan secara kolaboratif dan pertisipatif dengan tujuan memperbaiki kinerjanya sebagai guru, sehingga 
hasil belajar siswa dapat meningkat (Arikunto, Suhardjono, 2014).

\section{Prosedur Peneliitan}

Perencanaan penelitian materi perubahan dan pelestarian lingkungan hidup kelas X SMAS Katolik St Gabriel Maumere dilaksanakan dalam dua siklus. Siklus I dan II terdiri dari 6 kali pertemuan dengan dengan rincian $4 \mathrm{x}$ pertemuan kegiatan belajar mengajar dan $2 \mathrm{x}$ tes pada akhir siklus. Kegiatan belajar mengajar dalam 1 minggu dilakukan sebanyak $2 x$ pertemuan. Tiap siklus akan dilaksanakan secara bertahap sesuai dengan perubahan dan target yang ingin dicapai. Prosedur penelitian ini terdiri dari dua siklus, masing-masing siklus terdiri dari empat tahapan yaitu perencanaan, pelaksanaan, observasi dan refleksi.

\section{Pengumpulan Data}

Teknik atau cara pengumpulan data dalam penelitian ini terbagi atas dua bagian. Pertama yaitu observasi selama pembelajaran dilakukan dengan mengamati aktivitas siswa selama pelajaran. Dan yang kedua ialah pemberian test, teknik ini digunakan untuk mengetahui peningkatan hasil belajar siswa dengan guru memberikan soal dan siswa menjawabnya. Tes dilakukan sebanyak 3 kali selama penelitian pendahuluan, posttest siklus I dan posttest siklus II untuk mengetahui hasil belajar siswa setelah penerapan model Discovery learning.

\section{Analisis Data}

Data yang dianalisis terbagi atas dua macam yaitu, hasil belajar individu dan rata-rata nilai kelompok. Hasil belajar siswa ditentukan berdasarkan hasil tes yang telah dilaksanakan dengan menggunakan instrumen yang telah dibuat (Sukoco, Rumiyanti., \& Hidayah, 2016). Rumus yang digunakan untuk menentukan hasil belajar individu yaitu:

$$
\text { Nilai }=\frac{\text { Jumlah Skor Perolehan }}{\text { Skor Maksimal }} \times 100
$$

Nilai rata-rata kelompok dihitung menggunakan mean. Mean adalah teknik penjelasan kelompok yang didasarkan atas nilai rata-rata dari kelompok tersebut. Rumus perhitungan mean yang adalah:

$$
M e=\frac{\sum X i}{n}
$$

Keterangan :

Me : rata-rata

$\Sigma x i$ : jumlah nilai

$\mathrm{N}$ : jumlah siswa yang mengikuti tes (Sudjana, 2012).

Penyajian hasil tes menggunakan teknik presentase. Berikut adalah rumus untuk menentukan presentase kelulusan:

$$
\text { Presentase }=\frac{\text { jumlah lulusan KKM }}{\text { jumlah peserta didik }} \times 100
$$

\section{HASIL}

Hasil observasi studi awal di SMAS Katolik St Gabriel Maumere bahwa sebagian besar siswa masih mendapatkan nilai dibawah KKM yang ditetapkan sekolah. Adapun hasil observasi awal disajikan pada Gambar 1.

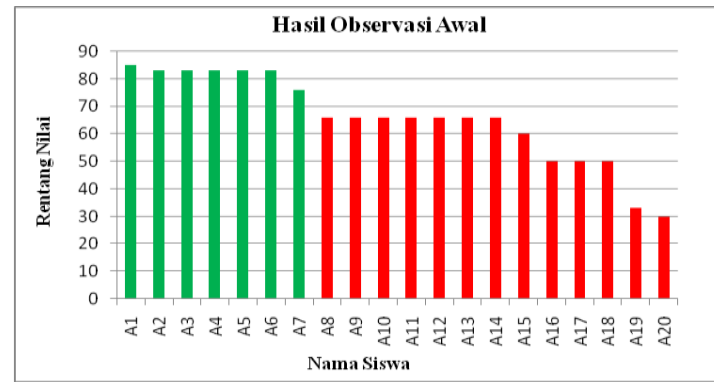

Gambar 1. Grafik Hasil Observasi Awal

Berdasarkan Gambar 1. hasil observasi awal yang telah dilakukan di SMAS Katolik St Gabriel Maumere, bahwa sebagian besar siswa nilainya belum mencapai KKM dengan rentangan nilai 30 sampai dengan 66. Hal ini dikarenakan pembelajaran masih cenderung berpusat pada guru (teacher centered) (Istiana. et al., 2015). Siswa kurang antusias, kurang aktif dan tidak terpacu untuk menemukan atau mencari informasi-informasi mengenai materi pembelajaran yang sedang dipelajari sehingga hasil belajar siswa rendah. Berdasarkan hasil observasi awal, maka peneliti memutuskan untuk menggunakan model discovery learning untuk meningkatkan hasil belajar siswa. Penelitian ini 
dilaksanakan dalam dua siklus dimana tiap-tiap siklus terdiri dari empat tahapan, yaitu: perencanaan, pelaksanaan, observasi, dan refleksi.

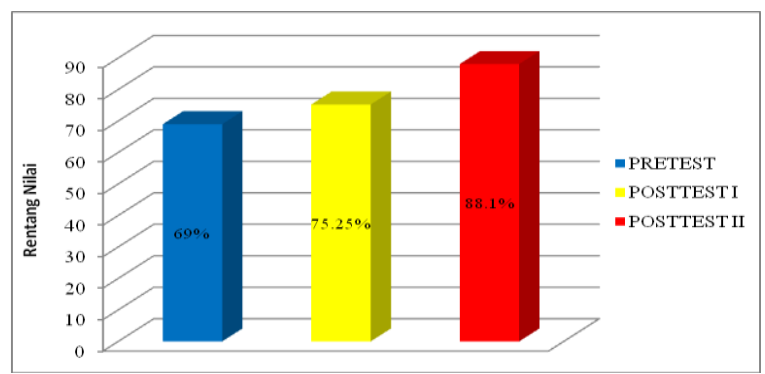

Gambar 2. Hasil belajar pretest, posttest I, dan Posttest II

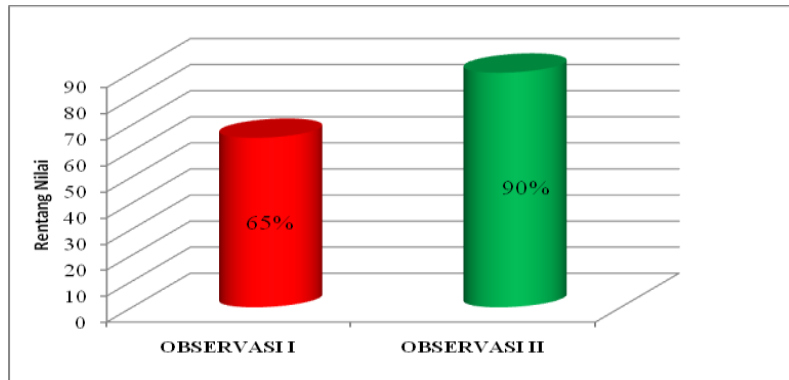

Gambar 3. Hasil observasi aktivitas siswa siklus I dan II pada pembelajaran Discovery

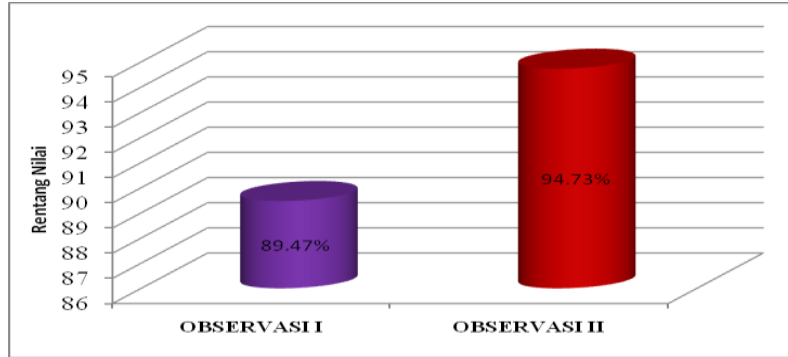

Gambar 4. Hasil observasi aktivitas guru siklus I dan II pada pembelajaran Discovery

\section{PEMBAHASAN}

Hasil yang diperoleh pada siklus I yaitu dengan nilai rata-rata 75,25 dan presentase ketuntasan 55\%. Hasil observasi aktivitas belajar siswa mencapai $65 \%$ sedangkan hasil observasi aktivitas guru mencapai 89,47\%. Hal ini dikarenakan ada beberapa siswa yang belum berani bertanya apa yang belum dipahami dan belum aktif dalam proses pembelajaran. Dengan melihat hasil yang dicapai pada siklus I, maka proses pembelajaran dilanjutkan ke siklus II untuk memperbaiki hasil belajar siswa pada siklus I.
Sukardi, Wigati \& Masripah (2015), menyatakan bahwa siswa dapat aktif jika diberikan metode pembelajaran yang tepat. Pembelajaran aktif juga dimaksudkan untuk menjaga perhatian siswa agar tetap tertuju pada proses pembelajaran. Guru mempunyai peranan yang penting agar siswa aktif dalam proses belajar dan memperoleh hasil belajar yang memuaskan, hal ini sejalan dengan penelitian Febriyanti \& Seruni (2014) semakin baik interaksi siswa dan guru dan semakin tinggi minat belajar siswa secara bersama-sama maka akan semakin baik juga hasil belajar tersebut. Oleh karena itu, guru hendaknya mampu memilih metode pembelajaran yang tepat dalam proses belajar, sehingga meningkatkan hasil belajarnya.

Berdasarkan hasil penelitian diatas dapat dikatakan bahwa ketuntasan belajar siswa dapat dicapai dengan menerapkan model discovery learning. Hal ini tidak terlepas dari semakin meningkatnya aktivitas guru dan aktivitas siswa dalam proses pembelajaran. Pentingnya aktivitas siswa dalam proses belajar mengajar hendaknya menjadi perhatian khusus bagi guru karena sebagai pengajar berkewajiban membimbing kegiatan belajar siswa sehingga siswa mau berperan aktif dalam belajar. Aktivitas siswa sangat penting agar hasil belajar yang diperoleh menjadi optimal, karena aktivitas sangat menentukan hasil belajar siswa. Seorang siswa yang akivitas belajarnya tinggi akan memperoleh hasil belajar yang memuaskan, dan sebaliknya apabila aktivitas belajar siswa rendah hasil belajarnya juga rendah.

Puspitadewi, N.C. \& Ashadi (2016) menjelaskan bahwa model Discovery Learning menekankan pentingnya pemahaman suatu konsep melalui keterlibatan siswa secara aktif dalam proses pembelajaran, sehingga dapat meningkatkan partisipasi siswa dan pembelajaran yang dipelajari lebih bermakna. Tanpa aktivitas belajar tidak akan memberikan hasil yang baik.

Model discovery learning berhasil meningkatkan hasil belajar siswa kelas X SMAS Katolik St Gabriel Maumere pada materi perubahan dan pelestarian lingkungan hidup, 
dengan presentase ketuntasan pada siklus I adalah 55\% sedangkan siklus II $90 \%$. Hal ini dikarenakan siswa aktif dalam menemukan konsep-konsep dan prinsip-prinsip melalui proses mentalnya sendiri.

Roestiyah (2008); Sukardi et al. (2015), menyatakan bahwa Discovery Learning dapat mengarahkan keaktifan siswa, dalam pembelajaran sehingga siswa tidak lagi ditempatkan dalam posisi pasif sebagai penerima bahan ajaran yang diberikan guru, tetapi sebagai subyek yang aktif melakukan proses berfikir, mencari, mengolah, menguasai dan menyelesaikan masalah.

Penelitian ini hanya menggunakan kriteria penilaian kognitif, yang diambil dari nilai setelah proses pembelajaran dengan menggunakan model Discovery Learning. Hasil selama pembelajaran dinyatakan bahwa rata-rata hasil belajar siswa dalam siklus II lebih tinggi dari pada siklus I, yang dilihat dari presentase ketuntasan hasil belajar siklus I dan II

\section{KESIMPULAN}

Penggunaan model Discovery learning dapat meningkatkan hasil belajar siswa pada pembelajaran Biologi pokok bahasan perubahan dan pelestarian lingkungan hidup kelas X MIA 2 di SMAS katolik St Gabriel Maumere Tahun Ajaran 2017/2018 yang dibuktikan dengan nilai hasil belajar siswa pada siklus II dengan rata-rata nilai yang dicapai 88,1 dan presentase kelulusan yang dicapai $90 \%$.

\section{REFERENSI}

Arikunto, Suhardjono, S. (2014). Penelitian Tindakan Kelas. Jakarta: Bumi Aksara.

Arikunto. S. (2016). Dasar-dasar Evaluasi Pendidikan. Jakarta: Bumi Aksara.

Djamarah, S. B., \& Zain, A. (2010). Strategi Belajar Mengajar. Jakarta: Rineka Cipta.

Febriana, D., Sajidan., \& Prayitno. (2015). Pengembangan Multimedia Interaktif Berbasis Group Discovery Learning (GDL) Pada Materi Protista. Jurnal Inkuiri, 4(2), 97-108.

Febriyanti, C., \& Seruni. (2014). Peran Minat Dan Interaksi Siswa Dengan Guru Dalam
Meningkatkan Hasil Belajar Matematika. Jurnal Formatif, 4(3), 245-254.

Fitriyah, Murtadlo, A., \& Warti, R. (2017). Pengaruh Model Pembelajaran Discovery Learning Terhadap Hasil Belajar Matematika Siswa Man Model Kota Jambi. Jurnal Pelangi, 9(2), 108112.

https://doi.org/http://dx.doi.org/10.22202/jp.2017 .v9i2.1898

Hamalik, O. (2015). Kurikulum dan Pembelajaran. Jakarta: Bumi Aksara.

Hamdani. (2011). Strategi Belajar Mengajar. Bandung: Pustaka Setia.

Istiana., Catur. A. N., S., \& J., S. (2015). Penerapan Model Pembelajaran Discovery Learning untuk Meningkatkan Aktivitas dan Prestasi Belajar Pokok Bahasan Larutan Penyangga Pada Siswa Kelas XI IPA Semester II SMA Negeri 1 Ngemplak Tahun Pelajaran 2013/2014. Jurnal Pendidikan Kimia. Universitas Sebelas Maret.

Puspitadewi, H., N.C., S. A., \& Ashadi. (2016). Penerapan Model Pembelajaran Discovery Learning Untuk Meningkatkan Minat Dan Prestasi Belajar Siswa Pada Materi Kelarutan Dan Hasil Kali Kelarutan Kelas Xi Mia 3 Semester Genap Sma N 1 Teras. Jurnal Pendidikan Kimia (JPK), 5(4), 114-119.

Roestiyah. (2008). Strategi Belajar Mengajar. Jakarta: Rineka Cipta.

Sudjana, N. (2012). Penilaian Hasil Proses Belajar Mengajar. Bandung: Remaja Rosdakarya.

Sugiyono. (2017). Metode Penelitian Pendidikan. Bandung: Alfabeta.

Sukardi, I., Wigati, I., \& Masripah, I. (2015). Pengaruh Metode Pembelajaran Discovery Learning Terhadap Hasil Belajar Siswa Pada Mata Pelajaran Biologi Kelas VII di MTs Patra Mandiri Plaju Palembang. Bioilmi, 1(1), 22-29.

Sukoco, Rumiyanti., \& Hidayah, S. (2016). Biologi Peminatan Matematika dan Ilmu-Ilmu Alam. Klaten: Intan Pariwara.

Wahjudi, E. (2015). Penerapan Discovery Learning Dalam Pembelajaran IPA Sebagai Upaya Untuk Meningkatkan Hasil Belajar Siswa Kelas IX-I Di SMP Negeri 1 Kalianget. Jurnal Lentera Sains, $5(1), 1-16$. 